Brit. F. vener. Dis. (1971) 47, 162

\title{
Validity of the VDRL test on cerebrospinal fluid contaminated by blood
}

\author{
N. N. IZZAT, J. K. BARTRUFF, J. M. GLICKSMAN, W. R. HOLDER, AND J. M. KNOX \\ Department of Dermatology and Syphilology, Baylor College of Medicine, and Syphilology Research Laboratory, \\ Veterans Administration Hospital, Houston, Texas
}

One of the most useful criteria for the diagnosis or exclusion of neurosyphilis is the result of a VDRL test performed on cerebrospinal fluid (CSF) obtained by lumbar puncture. A 'bloody tap' occurs in about 10 per cent. of lumbar punctures (Solomon, 1935). How valid is a reactive serological test for syphilis on CSF from a 'bloody tap'? Although several investigators have evaluated the problem of the reliability of the Wassermann test (Kafka, 1930; Stalder and Strehler, 1932; Solomon, Dailey, and Fremont-Smith, 1934; Foord and Bauckus, 1927) and the Kahn test (Loveman and Stocking, 1934) performed on CSF contaminated with blood, this is the first publication to evaluate the validity of the VDRL test in such cases.

\section{Material and methods}

BLOOD SOURCE

Clotted and whole blood specimens were collected in 'vacutainer' tubes, plain and containing ethylenediamine tetra-acetic acid (EDTA, Disodium), respectively. These specimens were obtained from 33 cases of untreated primary, secondary, early, and late latent cases of syphilis from the Houston Social Hygiene Clinic. All specimens were subjected to the test procedures within 6 hours of collection. Control specimens were likewise collected from donors with no history of venereal disease.

\section{CSF SOURCE}

CSF obtained by lumbar puncture was collected from hospitals associated with the Texas Medical Center. Specimens were excluded which were reported by the participating hospital laboratory to have either red cells or an elevated white cell count on microscopical examination, a reactive VDRL test, or an abnormal protein content. The specimens were then pooled and frozen at $-70^{\circ} \mathrm{C}$. until the test procedures were performed.

\section{EXPERIMENTAL PROCEDURE}

VDRL slide tests were performed according to the United States Department of Health Manual for Syphilis (1969) on both the clotted and EDTA blood specimens. Haematocrit determinations were performed on oxalated blood

Received for publication September 28, 1970

*Present address: Medical Arts Clinic, Corsicana, Texas specimens and the number of red blood cells per ml. was determined by use of a Coulter counter. 5-ml. serological pipettes were used to add $1 \mathrm{ml}$. of the seronegative pooled CSF to each of a series of 5-ml. serological tubes. Lambda $(0.001 \mathrm{ml}$.) increments $(1,3,6,10,20,35$, and 50$)$ of the EDTA blood specimens were added by lambda micro pipettes and VDRL slide tests were then performed on each tube. The amount of whole blood necessary to change the CSF from VDRL nonreactive to a reactive undiluted reading (as agreed upon by two laboratory technicians) was determined. The number of red blood cells per ml. mixture was calculated from the volumes of whole blood added on which the number of red blood cells per ml. had been determined by the Coulter counter.

The CSF-blood mixtures were observed under ordinary fluorescent room lighting to determine the presence or absence of visible blood.

\section{Results}

In a series of 33 separate experiments, the average amounts of syphilitic blood necessary to effect sero-conversion of the CSF were inversely proportional to the original VDRL titres (Table and Fig. 1). These amounts varied from 50 lambda of

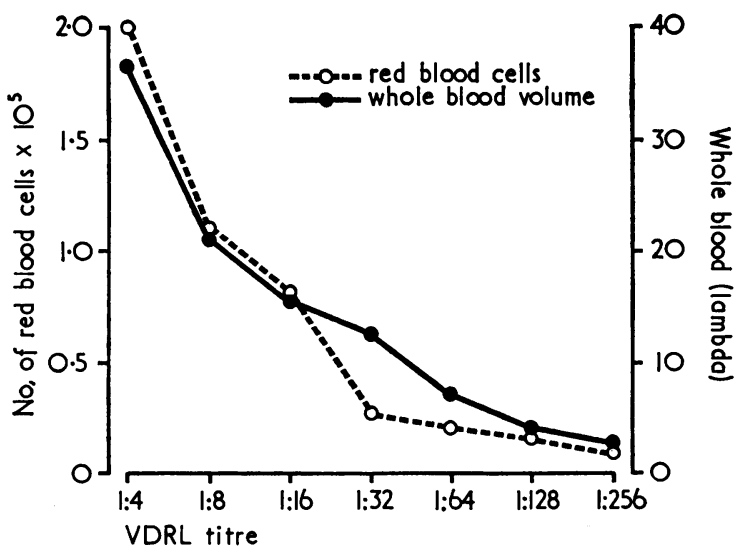

FIG. 1 Blood volumes and number of red blood cells required to effect seroconversion of $1 \mathrm{ml}$. CSF. 
blood with a $1: 1$ titre to as little as 3 lambda of blood with a VDRL titre of $1: 256$.

TABLE Syphilitic blood required to change $1 \mathrm{ml}$. CSF from VDRL negative to positive

\begin{tabular}{|c|c|c|c|}
\hline \multirow[t]{2}{*}{ Blood VDRL titre } & \multirow[t]{2}{*}{ No. tested } & \multicolumn{2}{|c|}{$\begin{array}{l}\text { Average blood necessary to convert } \\
1 \mathrm{ml} . \mathrm{CSF} \text { to VDRL reactive }\end{array}$} \\
\hline & & Volume (lambda) & No. $R B C s \times 10^{5 \star}$ \\
\hline $\begin{array}{l:l}1 & : 1 \text { (UND) } \\
1 & : 4 \\
1 & : 8 \\
1 & : 16 \\
1 & : 32 \\
1 & : 64 \\
1 & : 128 \\
1 & : 256\end{array}$ & $\begin{array}{r}2 \\
3 \\
5 \\
7 \\
10 \\
2 \\
2 \\
2\end{array}$ & $\begin{array}{r}50 \cdot 0 \\
36 \cdot 6 \\
21 \cdot 0 \\
16 \cdot 0 \\
13 \cdot 4 \\
8 \cdot 0 \\
4 \cdot 5 \\
3 \cdot 0\end{array}$ & $\begin{array}{l}-\dagger \\
2 \cdot 02 \\
1 \cdot 14 \\
0 \cdot 81 \\
0 \cdot 32 \\
0 \cdot 22 \\
0 \cdot 21 \\
0 \cdot 12\end{array}$ \\
\hline $\begin{array}{l}\text { Nonreactive } \\
\text { control }\end{array}$ & 1 & - & $-\dagger$ \\
\hline
\end{tabular}

*These counts were done on a Coulter counter

tRed blood cell counts were not done on these samples

The number of added red blood cells required to cause the CSF conversion correlated very closely with the volumes of blood added. As the peripheral blood VDRL titre increased, the red blood cell counts effecting sero-conversion decreased. The amounts of red blood cells ranged between 202,000 (for $1: 4$ titred blood) to 12,000 (for $1: 256$ titred blood) per $1 \mathrm{ml}$. CSF-blood mixture (Table).

The quantity of whole blood, at titres of $1: 256$ or less, sufficient to effect sero-conversion of the
CSF, always resulted in a visibly bloody mixture (Fig. 2). Quantities of whole blood which did not? produce a bloody appearance did not cause CSFO sero-conversion, even though there were too manyo cells to count when the mixture was observed microscopically on the Haemacytometer.

\section{Discussion}

In the early 1930 s several investigations were carried. out to determine the serological effect of blood upon $\vec{\omega}$ CSF. Kafka (1929) advised that, in the case of the 'bloody tap', the amount of blood in the specimen:should be estimated, and that the amount should be added to normal CSF and the Wassermann result $\omega$ noted. If the CSF remained negative, he felt that $\vec{\sigma}$ the serological results of the 'bloody tap' could be relied upon. Stalder and Strehler (1932) failed to find uniformity of results with Kafka's method, and felt $\vec{c}$ that the lumbar puncture should be repeated if the Wassermann reaction were positive in the cases in $\mathbb{\Phi}$ which the CSF was contaminated with blood. Love- $\vec{\theta}$ man and Stocking (1934) added varying amounts of serum from syphilitic patients to normal cerebrospinal fluids and calculated that as little as $0.003 \mathrm{~m}$. of high titred whole blood could convert $6 \mathrm{ml}$. of CSF from Kahn negative to positive. Foord and Bauckus (1927) found that as little as $0.01 \mathrm{ml}$. serum $\frac{\mathrm{D}}{\varnothing}$ or $0.015 \mathrm{ml}$. whole blood could convert the Wassermann reaction of $2 \mathrm{ml}$. CSF from negative to positive. They noted that even $0.005 \mathrm{ml}$. whole blood

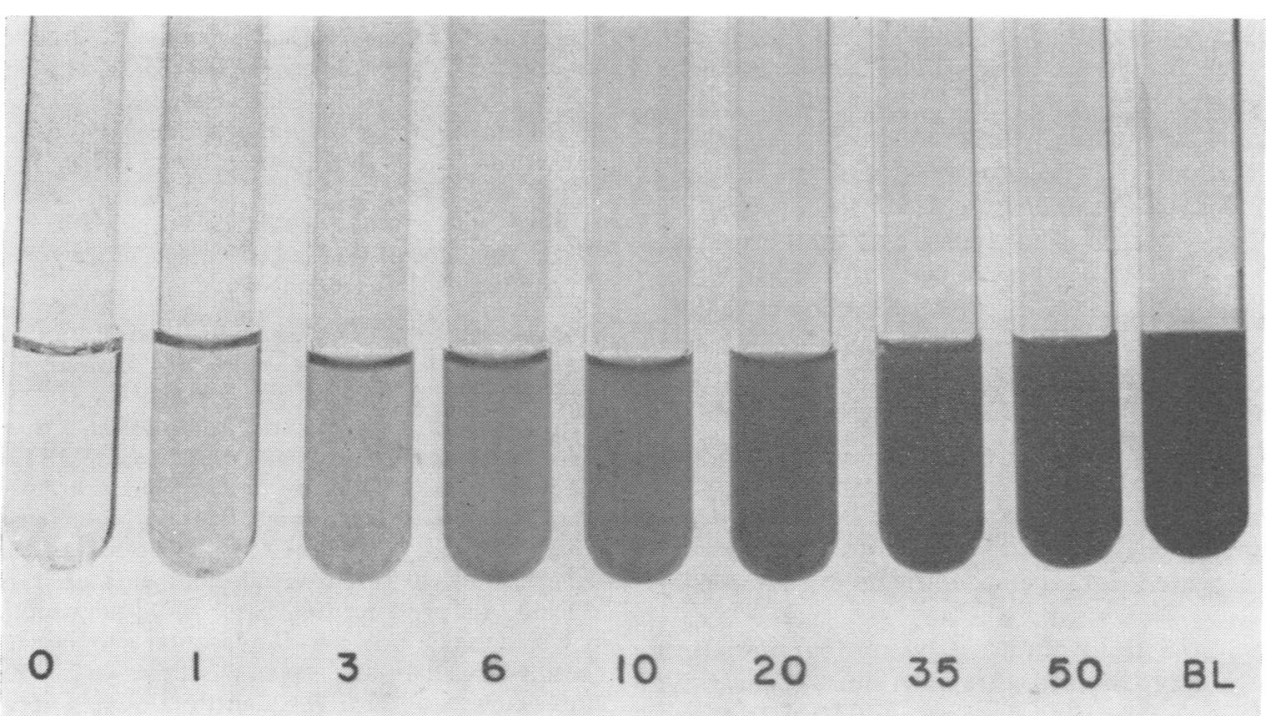

FIG. 2 Appearance of experimentally contaminated CSF with serially diluted whole syphilitic blood with a haematocrit of 44 per cent. Numerals indicate numbers of $0.001 \mathrm{ml}$. increments of blood added to $1 \mathrm{ml}$. CSF. $B L=$ whole blood 
in $2 \mathrm{ml}$. CSF resulted in a visibly bloody colour of the mixture and felt that microscopic amounts of blood could be ignored. Solomon and others (1934) agreed with the findings of Foord and Bauckus.

Analysis of our data indicated that as little as 3 lambda $(0.003 \mathrm{ml}$.) of whole blood with a titre of $1: 256$ could convert $1 \mathrm{ml}$. of VDRL nonreactive CSF to reactive. This amount is approximately equivalent to the whole blood estimated by Loveman and Stocking (1934) to be needed to change a CSF standard Kahn test from negative to positive. The volume of blood required to effect CSF seroconversion is inversely proportional to its titre, i.e. less blood is needed to cuuse serological conversion as the titre increases.

Our results are based on the hypothesis that whole blood causes the 'bloody tap'. In practice it is likely that the first few drops of contaminated CSF contain small amounts of lymphatic and tissue fluid and extravasated serum, thus in effect slightly lowering the haematocrit of the contaminating fluid. However, the amounts of whole blood with haematocrits ranging from 38 to 46 per cent. required to convert CSF from seronegative to seropositive did not vary to any significant degree between the haematocrits if the sera were of the same titre.

6 and 3 lambda of whole blood with a haematocrit of 38 per cent. resulted in a visibly blood-tinged appearance of $1 \mathrm{ml}$. CSF, whereas 1 lambda did not. 3 lambda of whole blood resulted in approximately 12,000 red blood cells per ml., a number which appears as 'too numerous to count' (TNTC) to the laboratory technicians using the Haemacytometer counting chamber.

In conclusion, the following points may be stressed: (1) The amount of whole blood contamination required to convert seronegative CSF to seropositive is inversely proportional to the titre of the peripheral blood.

(2) At titres of $1: 256$ or below, sufficient whole blood to cause a spuriously reactive CSF VDRL test causes a visibly bloody mixture.

(3) In cases in which the 'bloody tap' is detectable only microscopically, a reactive VDRL test reflects a truly reactive CSF serology.

(4) If the CSF is visibly bloody with both a reactive blood and CSF VDRL test, the lumbar puncture must be repeated for accurate diagnosis of neurosyphilis.

(5) If the initial fluid obtained by lumbar puncture is visibly bloody, discard that portion. Clear fluid which follows can be used for a reliable VDRL determination.

(6) Ordinarily the patient on whom a lumbar puncture is done to exclude neurosyphilis has a low titred reactive blood VDRL. This requires a relatively large amount of blood contamination to effect a falsely reactive CSF VDRL; therefore the "bloody tap' in such cases would have to be visibly bloody to produce a spuriously reactive VDRL.

\section{Summary}

The 'bloody tap' was experimentally reproduced as it might occur in syphilis patients by adding known quantities of VDRL reactive blood to nonreactive cerebrospinal fluid. The quantities of whole blood required to convert $1 \mathrm{ml}$. cerebrospinal fluid to seropositive ranged from 50 lambda $\star$ for $1: 1$ titre blood to 3 lambda for $1: 256$ titre blood. 3 lambda of whole blood per ml. of cerebrospinal fluid caused a definite blood colour, whereas 1 lambda did not. With VDRL titres of $1: 256$ or below, sufficient whole blood to cause a false positive cerebrospinal fluid VDRL test produces visibly bloody cerebrospinal fluid.

$\star 1$ lambda $=0.001 \mathrm{ml}$.

We wish to thank Miss S. E. McCotter and Miss C. R. Wills for excellent technical assistance. This investigation was supported by the John A. Hartford Foundation, Grant No. 2465.

\section{References}

Foord, A. G., and Bauckus, M. (1927) F. Lab. clin. Med., 13, 270

KaFKA, V. (1929) In 'Handbuch der Haut- und Geschlechtskrankheiten', ed. J. Jadassohn, band 17, teil 1, p. 513, Springer, Berlin.

Loveman, A. B., and Stocking, L. (1934) Arch. Derm. Syph. (Chicago), 29, 653

Solomon, P. (1935) New Engl. F. Med., 212, 55

-, DaIley, M. E., and Fremont-Smith, F. (1934) Arch. Neurol. Psychiat. (Chicago), 31, 1222

StALDER, W., and STREHLER, W. (1932) Schweiz. med. Wschr., 13, 752

United States Public Health Service (1969) P.H.S. Publication No. 411. United States Government Printing Office, Washington, D.C.

Valeur du test VDRL sur le liquide céphalorachidien (LCR) contaminé par du sang SOMMAIRE

Un dispositif expérimental fut imaginé, qui ajoutait des quantités connues de sang positif en VDRL à du LCR négatif pour reproduire ce qui peut arriver chez des syphilitiques. La quantité de sang total susceptible de rendre positif $1 \mathrm{ml}$. de LCR alla de 50 lambda $^{\star}$ pour un sang titrant de 1:1 à 3 lambda pour un sang positif à 1:256. La présence de 3 lambda de sang total par $\mathrm{ml}$. de LCR donnait une nette coloration sanglante, ce que ne faisait pas 1 lambda. Avec des titres en VDRL égaux ou inférieurs à $1: 256$, la quantité de sang total suffisante pour entraîner une fausse positivité du LCR détermine une coloration sanglante visible du liquide céphalorachidien.

$\star 1$ lambda $=0,001 \mathrm{ml}$. 